\title{
PEMBANGKITAN RAGAM BATIK KONTEMPORER DENGAN POLA MENGIKUTI GRUP KRISTALOGRAFI BIDANG
}

\author{
AGAH D.GARNADI ${ }^{1}$, PUTRANTO H. UTOMO ${ }^{2}$, FARIS S. ROMZA, MUCHAMMAD FACHRI, F. HANUM ${ }^{1}$ \\ ${ }^{1}$ Departemen Matematika \\ Fakultas Matematika dan IImu Pengetahuan Alam \\ Institut Pertanian Bogor \\ JI Meranti, Kampus IPB Darmaga \\ Bogor 16680 \\ Indonesia \\ ${ }^{2}$ Departemen Matematika \\ Fakultas Matematika dan Ilmu Pengetahuan Alam \\ Universitas Sebelas Maret \\ Surakarta 16680 \\ Indonesia
}

\begin{abstract}
Abstrak
Batik merupakan salah satu budaya Indonesia, khususnya di Jawa, yang perlu dikembangkan dan dilestarikan. Banyak produk yang menggunakan batik sebagai komponen utama, antara lain busana, lukisan, dan perlengkapan rumah tangga.

Dalam grup simetri kristalografi bidang datar terdapat pasti 17 tipe pola ulangan (kisi satuan) yang dapat menutupi bidang datar Tujuan utama penelitian ini adalah memanfaatkan kisi satuan untuk membentuk pola batik.

Dengan memanfaatkan pola kisi satuannya, dapat ditentukan sejumlah pola geometris dari batik. Batik dengan pola geometris tersusun dari berbagai unsur antara lain lingkaran, segiempat, segitiga dan berbagai bangun polygon yang beraturan. Batik dengan pola nongeometris tidak dapat ditentukan kisi satuannya, karena tidak ada pengulangan pola. Kisi satuan dari pola batik yang dipelajari mengumpul pada beberapa pola tertentu. Hal ini disebabkan karena kemudahan dari kisi satuan tersebut untuk dibuat dan penglihatan kita yang terbiasa dengan simetri dari kisi satuan tersebut.

Dengan menggunakan software grafis, dirintis upaya konstruksi sejumlah pola geometris batik baru, berdasarkan aturan kisi satuan yang diberikan.
\end{abstract}

Kata kunci: pola batik kontemporer, grup simetri, grup kristalografi bidang, etnomatematika. 


\section{PENDAHULUAN}

Batik merupakan salah satu seni budaya Indonesia yang patut dilestarikan dan dikembangkan. Banyak produk yang menggunakan batik sebagai komponen utama, antara lain busana, lukisan, perlengkapan rumah tangga (taplak meja, sarung bantal), dan sebagainya. Hasil karya putra-putri Indonesia ini tidak hanya disukai di negeri sendiri tetapi juga dikenal di banyak negara tetangga. Dengan perkataan lain, batik mempunyai nilai ekonomi yang tinggi di samping nilai keindahannya.

Batik merupakan bentuk motif atau pola dekoratif yang dilukiskan pada bidang datar. Motif atau pola dekoratif tersebut juga sebagai motif batik atau pola batik yang merupakan kerangka gambar yang membentuk batik secara keseluruhan. Motif dapat dibedakan dalam dua golongan besar yaitu:

a. golongan motif yang geometris, yaitu motif-motif yang tersusun atas unsur-unsur bentuk geometri seperti lingkaran, segiempat, segitiga, dan sebagainya;

b. golongan motif nongeometris yaitu motif-motif yang tersusun atas unsur-unsur bentuk nongeometris.

Ada dua unsur berbeda pada batik dengan motif-motif geometris yaitu desain atau motif yang merupakan kreasi dari desainer, dan pola yang merupakan cara pengulangan dari desain atau motif. Secara kasar boleh dikatakan bahwa batik dengan motif-motif geometris merupakan gambar (himpunan titik-titik pada bidang) yang polanya diulangulang sehingga tidak berubah. Secara matematis boleh dikatakan bahwa pengulangan pola adalah suatu transformasi yaitu pergeseran, perputaran, dan pencerminan yang mengakibatkan pola-pola batik tidak berubah.

\section{TINJAUAN PUSTAKA}

\subsection{Grup dan Simetri}

Grup adalah suatu gugus $G$ dengan operasi * pada $G$ yang memenuhi aksiomaaksioma: a) operasi * bersifat asosiatif pada $G$, b) gugus $G$ memuat unsur identitas terhadap *, dan c) setiap anggota $G$ mempunyai unsur invers dalam $G$ terhadap *. Suatu grup dikatakan komutatif jika operasinya bersifat komutatif.

Misalkan $S$ adalah sembarang gugus tidak kosong, dan misalkan $M(S)$ adalah gugus yang beranggotakan semua fungsi bijektif dari $S$ ke $S$. Maka $M(S)$ merupakan grup dengan komposisi fungsi sebagai operasi.

Misalkan $p$ adalah titik tertentu dalam suatu bidang dan $P$ menyatakan gugus semua titik pada suatu bidang. Misalkan $G$ menyatakan gugus yang beranggotakan semua rotasi bidang yang berpusat di $p$. Karena rotasi merupakan fungsi bijektif dari $P$ ke $P$, maka $G$ adalah grup terhadap operasi komposisi fungsi.

Misalkan $S$ adalah gugus yang tidak kosong. Permutasi dari gugus $S$ adalah fungsi bijektif dari $S$ ke $S$. Gugus yang beranggotakan semua permutasi dari $S$ merupakan grup terhadap operasi komposisi. Grup ini dinamakan grup simetri pada $S$, dinotasikan dengan $\operatorname{Sym}(S)$. Secara umum, sembarang grup yang memiliki anggota permutasipermutasi disebut grup permutasi. Dalam hal ini grup permutasi $S$ tidak harus memuat sermua permutasi pada $S$. Jika $S$ adalah gugus $\{1,2, \ldots, n\}$, dengan $n$ bilangan bulat positif, Sym $(S)$ dinotasikan dengan $S_{n}$.

Misalkan $H$ adalah anak gugus grup $G$. $H$ disebut subgrup dari $G$ jika dan hanya jika $H$ juga merupakan grup terhadap operasi yang sama dengan $G$. Misalkan $G$ adalah grup, $a \in G$, dan $\langle a\rangle$ menyatakan gugus yang beranggotakan semua kuasa dari $a$, yang ditulis $\langle a\rangle=\left\{a^{n} \mid n \in Z\right\}$. Maka $\langle a\rangle$ merupakan subgrup dari $G$ dan dinamakan 
subgrup yang dibangun oleh a. Jika $H$ adalah subgrup dan $H=\langle a\rangle$ untuk suatu $a \in H$, maka $H$ disebut subgrup siklik.

Banyak grup yang timbul dari keterkaitannya dengan simetri. Seperti halnya bilangan yang dapat digunakan untuk menentukan ukuran, grup dapat digunakan untuk mengukur simetri. Setiap gambar bidang yang dikaitkan dengan suatu grup, grup tersebut memberikan sifat padanya. Aplikasi dari teori grup ini merupakan perluasan dari geometri ke kristalografi.

\subsection{Transformasi}

Misalkan $P$ menyatakan gugus semua titik pada suatu bidang, dan $M$ menyatakan gugus semua permutasi dari $P$ yang mempertahankan jarak di antara titik-titiknya. Jadi, jika $p$ dan $q$ adalah dua titik dalam $P$, dan $m$ adalah permutasi di $M$, maka jarak antara $m(p)$ dan $m(q)$ adalah sama dengan jarak antara $p$ dan $q$. Permutasi-permutasi dalam $\mathrm{M}$ tersebut dinamakan isometri atau motion (pergerakan) pada bidang. Berikut ini diperkenalkan tiga tipe isometri, yaitu rotasi (perputaran), refleksi (pencerminan), dan translasi (pergeseran).

Jika $P$ adalah suatu titik tertentu dalam suatu bidang, maka rotasi bidang berpusat di $P$ merupakan isometri bidang. Suatu transformasi dengan perputaran memindahkan setiap titik $P$ ke $P$ ' sehingga $A P^{\prime}$ adalah $A P$ yang diputar sebesar $\theta$ dengan titik pusat $A$. Suatu perputaran sejauh $360^{\circ} / n$ yang mengakibatkan gambar tidak berubah dikatakan mempunyai pusat putaran lipat- $n$ dengan $n$ merupakan bilangan bulat.

Jika $P$ suatu titik dan I suatu garis sembarang maka pencerminan (refleksi) titik $P$ pada I menghasilkan $P^{\prime}$ sehingga jarak $P$ dengan garis I sama dengan jarak $P^{\prime}$ dengan garis $\ell$ dan juga $P P^{\prime}$ memotong tegak lurus garis $I$.

Pergeseran (translasi) pada bidang $P$ adalah suatu pemetaan dari setiap titik pada jarak dan arah yang sama.

Jika $\underline{t}$ adalah sembarang vektor pada bidang, didefinisikan translasi TT menjadi suatu transformasi yang memetakan $P$ ke $P^{\prime}$, sehingga $P P^{\prime}=\underline{t}$.

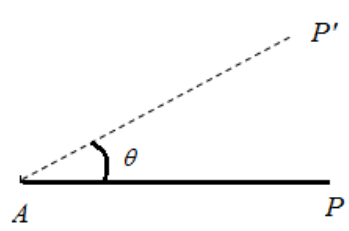

(a)

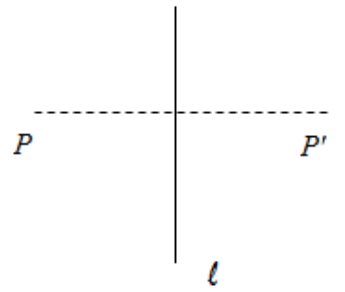

(b)

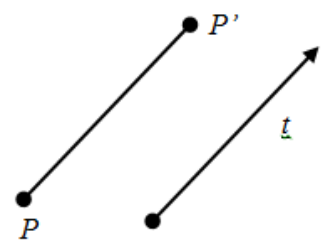

(c)

Gambar 1 (a) Perputaran, (b) pencerminan, (c) pergeseran

Jika $M$ adalah gugus yang beranggotakan semua isometri pada suatu bidang $P$, maka $M$ merupakan subgrup dari $\operatorname{Sym}(P)$. Dengan demikian $M$ merupakan grup terhadap operasi komposisi.

Suatu pengembangan atau perpaduan dari pergeseran dan pencerminan akan menghasilkan suatu transformasi baru yang disebut pantul geser (glide reflection). 


\section{METODE PENELITIAN}

Metode penelitian yang digunakan berdasarkan sejumlah tahapan :

1. studi eksplorasi melalui:

a. kajian pola batik yang telah ada dan diskusi pakar (perancang dan peneliti) batik,

b. penggunaan grup simetri berdasarkan pustaka (buku dan jurnal) dan diskusi pakar,

2. survey batik ke lembaga seni rupa, pengusaha, serta museum batik,

3. penelusuran penyebab pengelompokan pola ulangan melalui wawancara dengan pakar batik,

4. membuat rancangan batik baru berdasarkan dengan pola simetri yang digunakan.

\section{PEMBAHASAN}

\subsection{Grup Kristalografi}

Jika poligon-poligon yang kongruen dengan sisi-sisinya tidak saling overlap ditata, maka yang memenuhi bidang hanyalah segi empat, segitiga dan heksagonal (segi enam) seperti terlihat pada Gambar 2 berikut. Suatu bidang yang luas dapat diisi dengan poligon-poligon yang kongruen ini sehingga seluruh bidang terisi (tidak berlubang) dengan melakukan perputaran, pencerminan, pergeseran atau translasi terhadap poligon-poligon tersebut. Dengan cara ini akan didapatkan pola-pola simetri tertentu.
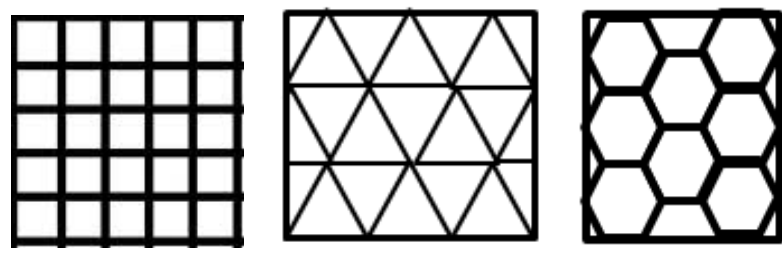

Gambar 2. Poligon pengisi bidang.

Grup yang berhubungan dengan masalah ini disebut grup simetri. Dalam hal ini terdapat 17 grup yang memenuhi kriteria tersebut. Ke-17 grup ini sering disebut sebagai grup kristalografi dua dimensi. Grup kristalografi ini merupakan grup simetri. Poligon terkecilnya disebut sebagai kisi satuan (lattice).

\subsection{Kisi Satuan}

Pada bab ini akan dibahas bahwa setiap pola ulangan memiliki gabungan dari titik-titik yang menjadi suatu kisi. Ambil sembarang titik di pola. Kisinya adalah himpunan dari bayanganbayangan titik-titik yang diakibatkan pergeseran dari sekelompok pola. Sebuah kisi satuan adalah sebuah jajaran genjang yang setiap titik sudutnya merupakan titik kisi. Vektor yang membentuk sisi dari sebuah kisi satuan dihasilkan dari pergeseran sekelompok pola. (Para ahli menggunakan istilah sel primitif untuk sebuah kisi satuan, beberapa yang lain menggunakan istilah sel satuan atau sel.) Di samping pergeseran, sebuah pola ulangan mungkin juga dipetakan kepada dirinya sendiri dengan beberapa isometri bidang: perputaran, pencerminan, dan pantul geser.

Grup isometri dari pola adalah himpunan dari seluruh isometri yang memetakan suatu pola atas dirinya sendiri. Grup simetri dari sebuah pola ulangan memetakan suatu gabungan kisi atas dirinya sendiri. Sebuah kisi satuan dapat memiliki lebih dari satu pusat putaran lipat- $n$. 
Sebuah kisi satuan dikatakan mempunyai orde- $n$ jika mempunyai pusat putaran lipat- $n$ yang tertinggi. Menurut Doris Schattschneider, terdapat lima tipe kisi satuan yang berbeda, yaitu jajaran genjang, persegi pajang, belah ketupat, bujur sangkar, dan heksagonal (yang tersusun dari dua segitiga sama sisi) seperti terlihat pada Gambar 3 berikut.

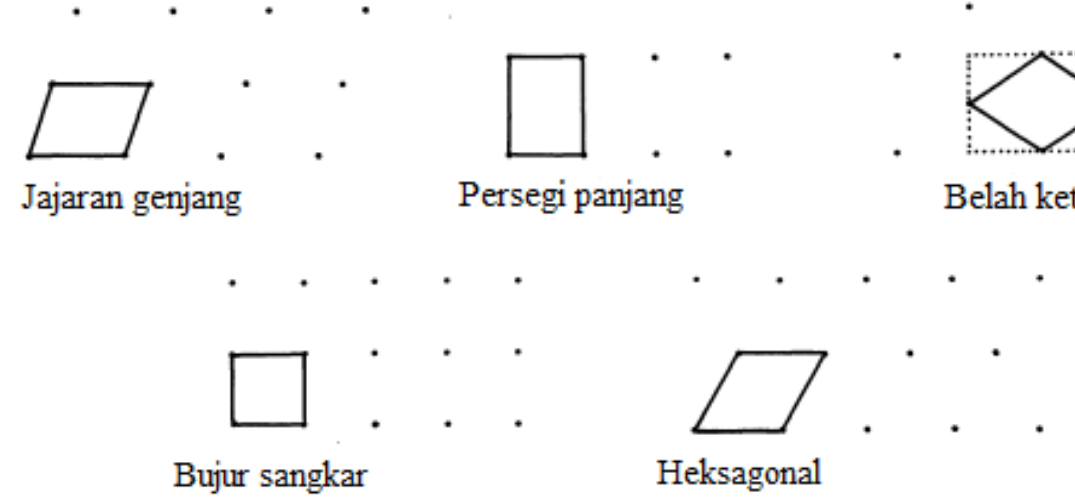

Gambar 3. Lima tipe kisi satuan.

Setiap jenis kisi satuan dapat membentuk pola dengan bantuan suatu transformasi tertentu. Menurut Schattschneider, terdapat 17 tipe grup kristalografi berbeda yang dapat dilihat pada Gambar 4 berikut.

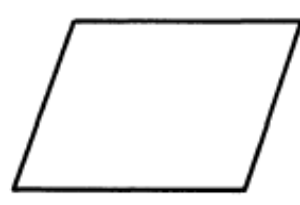

$p 1$

$(p 1)$

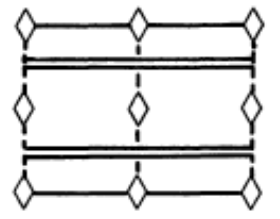

pmg

$(p 2 m g)$

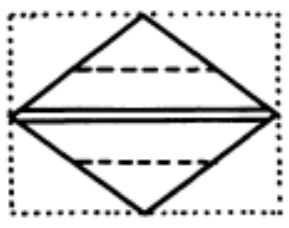

$\mathrm{cm}$

(c1m1)

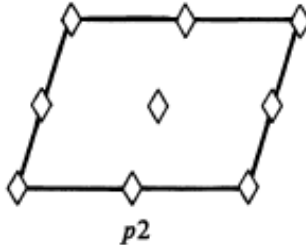

(p211)

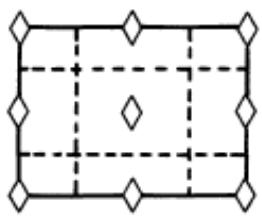

pgg

(p2gg)

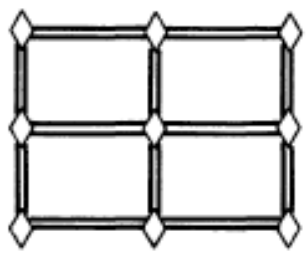

pmm

(p2 $2 \mathrm{~mm})$

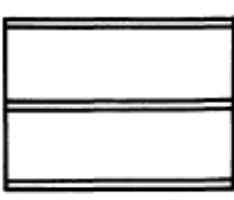

pm

(p1ml)

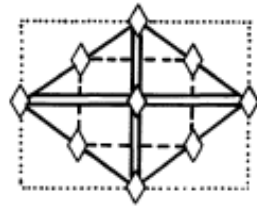

cmm

(c2mm)

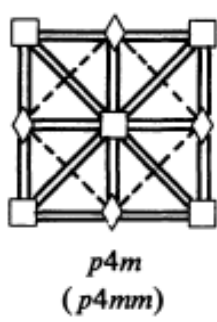

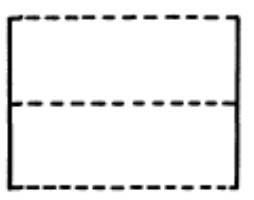

pg

( $p 1 g 1)$
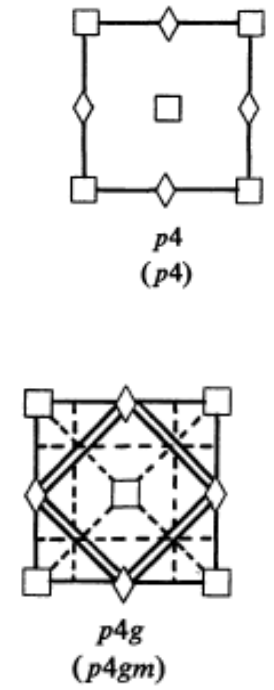

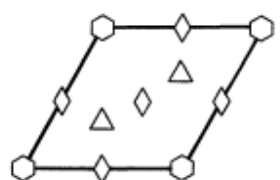

p6

(p6)

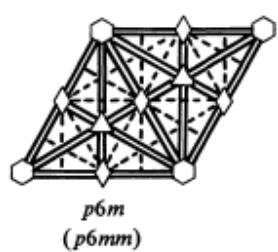




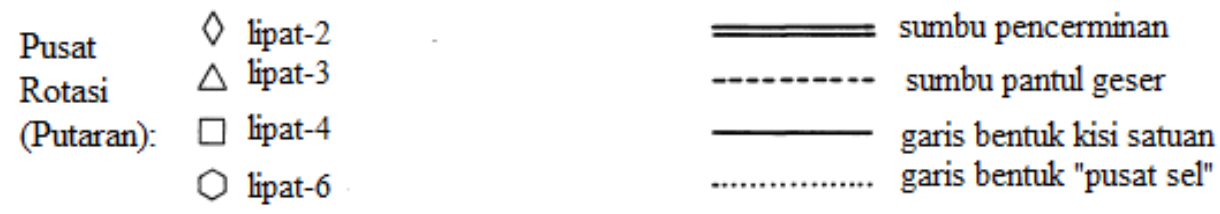

Gambar 4. Grup kristalografi 2 dimensi

Dalam penggolongan tersebut terdapat beberapa notasi, antara lain:

1. Huruf $p$ dan $c$ menyatakan sel primitif (kisi satuan) atau sel terpusat. Pada umumnya sel primitif mempunyai pusat-pusat dengan orde perputaran tertinggi berada pada titik-titik kisi, sedangkan sel terpusat mempunyai sumbu pencerminan yang tegak lurus dengan satu atau dua sisi sel.

2. Bilangan bulat $n$ menunjukkan orde atau tingkat perputaran yang tinggi.

3. Simbol yang menunjukkan bahwa sumbu simetri tegak lurus dengan sumbu- $x$ dari sel (yaitu sisi kiri dari sel) ialah $m$ (mirror) menyatakan sumbu pencerminan, $g$ menyatakan tidak ada pencerminan melainkan sumbu pantul geser (glide reflection).

4. Simbol yang menunjukkan sebuah sumbu simetri pada sudut $\alpha$ terhadap sumbu $x$, dengan $\alpha$ bergantung pada $n$, orde atau tingkat perputaran yang tertinggi: $\alpha=180^{\circ}$ untuk $n=1$ atau $n=2, \alpha=45^{\circ}$ untuk $n=4, \alpha=60^{\circ}$ untuk $n=3$ atau $n=6$.

Untuk mengklasifikasikan suatu pola ke dalam salah satu model dari 17 kisi satuan, berikut ini disediakan daftar untuk mengenali pola bidang ulang.

Tabel 1. Ciri pola-pola ulangan

\begin{tabular}{|c|c|c|c|c|c|}
\hline $\begin{array}{l}\text { Model } \\
\text { Kisi } \\
\text { Satuan }\end{array}$ & Kisi & Orde & Pencerminan & $\begin{array}{l}\text { Pantul } \\
\text { Geser }\end{array}$ & Keterangan \\
\hline$p 1$ & jjg & 1 & tidak ada & tidak ada & \\
\hline p2 & jjg & 2 & tidak ada & tidak ada & \\
\hline$p m$ & ppj & 1 & ada & tidak ada & \\
\hline$p g$ & ppj & 1 & tidak ada & ada & \\
\hline $\mathrm{cm}$ & bkt & 1 & ada & ada & \\
\hline$p m m$ & ppj & 2 & ada & tidak ada & \\
\hline pmg & ppj & 2 & ada & ada & $\begin{array}{l}\text { sumbu } \\
\text { simetri } \\
\text { sejajar }\end{array}$ \\
\hline pgg & ppj & 2 & tidak ada & ada & \\
\hline $\mathrm{cmm}$ & bkt & 2 & ada & ada & $\begin{array}{l}\text { sumbu } \\
\text { simetri saling } \\
\text { tegak lurus }\end{array}$ \\
\hline$p 4$ & bks & 4 & tidak ada & tidak ada & \\
\hline$p 4 m$ & bsk & 4 & ada & ada & $\begin{array}{l}\text { pusat-4 pada } \\
\text { sumbu } \\
\text { cermin }\end{array}$ \\
\hline$p 4 g$ & bsk & 4 & ada & ada & $\begin{array}{l}\text { pusat-4 tidak } \\
\text { pada sumbu } \\
\text { cermin }\end{array}$ \\
\hline p3 & hks & 3 & tidak ada & tidak ada & \\
\hline$p 3 m 1$ & hks & 3 & ada & ada & $\begin{array}{l}\text { semua pusat- } \\
3 \quad \text { pada } \\
\text { sumbu }\end{array}$ \\
\hline
\end{tabular}




\begin{tabular}{|c|l|l|l|l|l|}
\hline$p 3 m 1$ & hks & 3 & ada & ada & $\begin{array}{l}\text { tidak semua } \\
\text { pusat-3 pada } \\
\text { sumbu } \\
\text { cermin }\end{array}$ \\
\hline$p 6$ & hks & 6 & tidak ada & tidak ada & \\
\hline$p 6 m$ & hks & 6 & ada & ada & \\
\hline
\end{tabular}

Keterangan :

jjg : jajaran genjang,

bsk : bujur sangkar,

ppj : persegi panjang,

bkt : belah ketupat

hks : heksagonal

\subsection{Algoritme Penentuan Tipe Kisi Satuan}

Telah diketahui bahwa setiap pola geometris pasti mempunyai pola ulangan yang merupakan salah satu dari ketujuh belas kisi satuan yang ada, demikan pulalah halnya dengan batik yang mempunyai pola geometris. Untuk dapat menggolongkan setiap pola batik dengan pola geometris ke dalam salah satu dari ketujuh belas kisi satuan yang ada, maka digunakan algoritme Durbin (1985) yang dapat disarikan sebagai berikut.

Gambar 5. Algoritme penentuan kisi satuan.

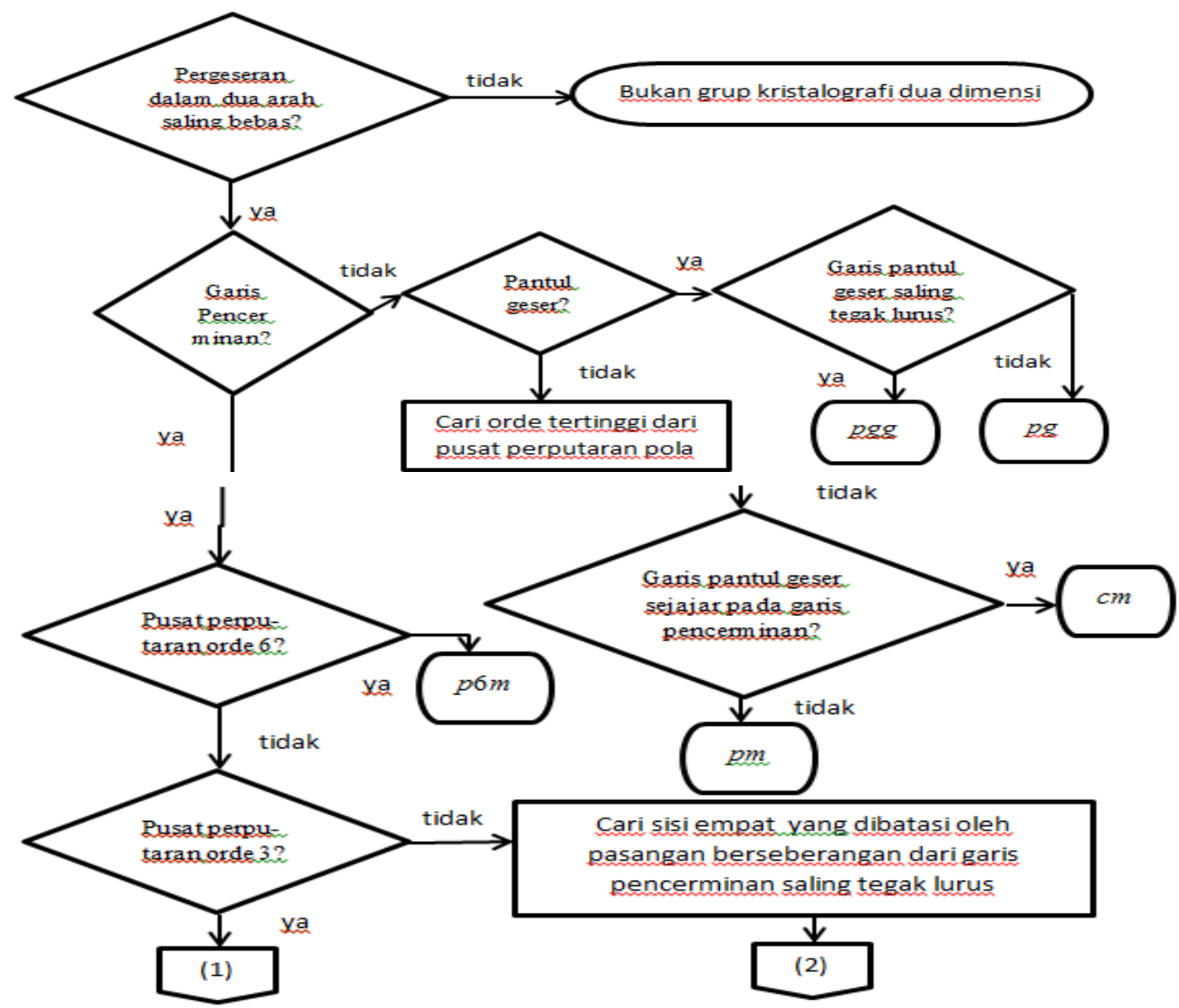


(1)

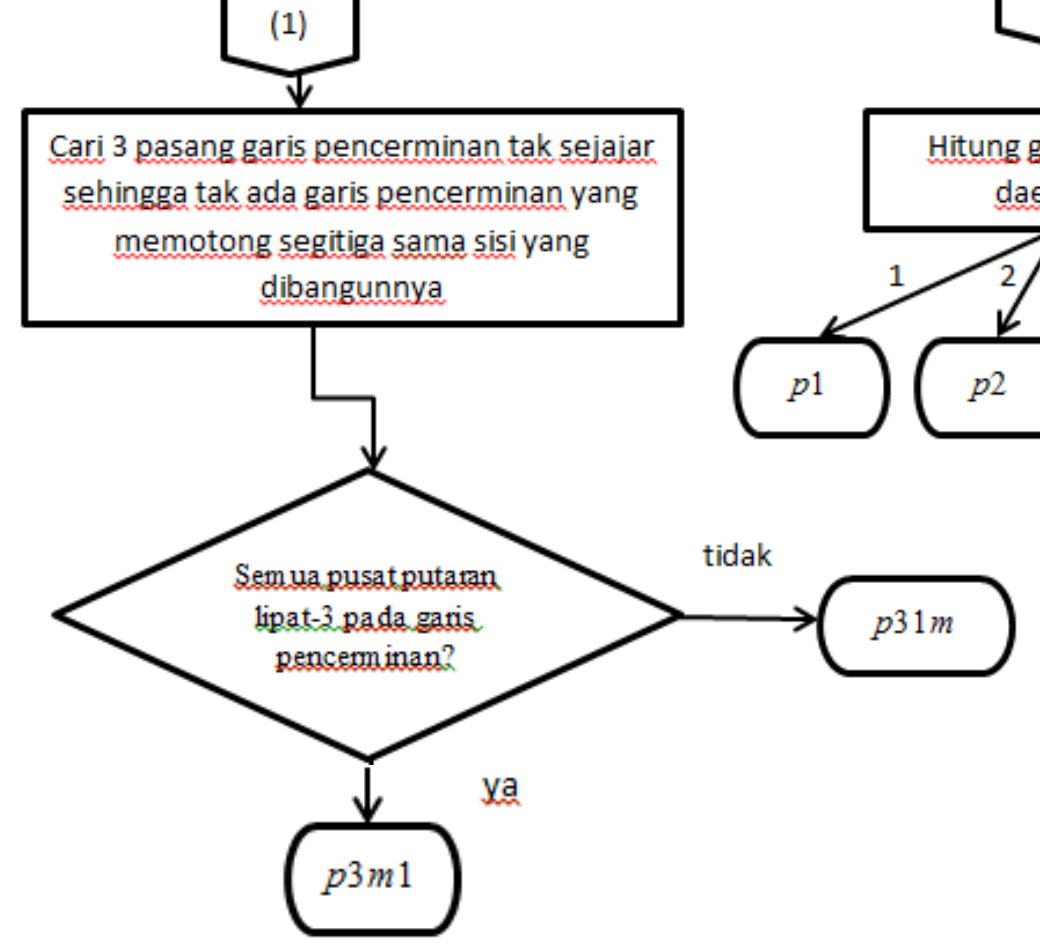

(2)

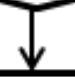

$y$ daerah isi 


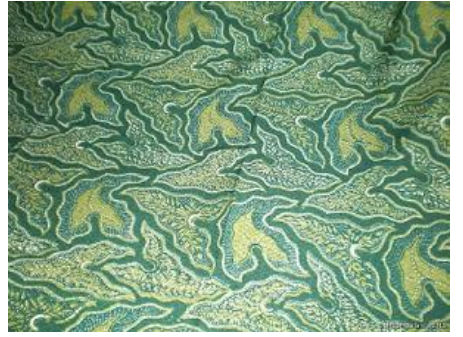

Motif: Godong Lumbu

Tipe kisi satuan: $p 1$

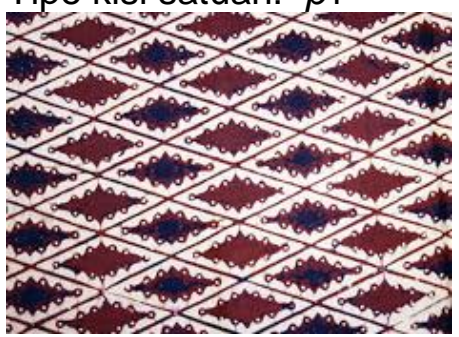

Motif: Limaran

Tipe kisi satuan: $p m m$

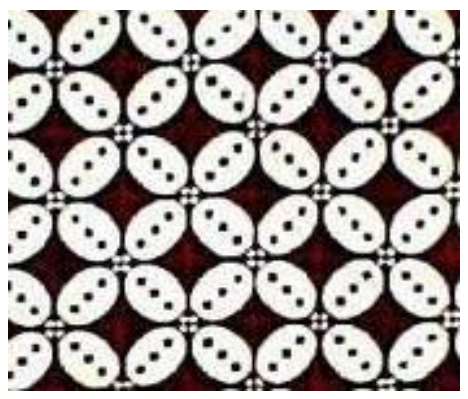

Motif: Kawung Benggol

Tipe kisi satuan: $p 4 m$

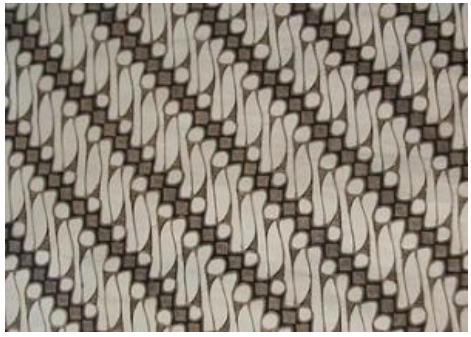

Motif: Parang Rusak

Tipe kisi satuan: $p 2$

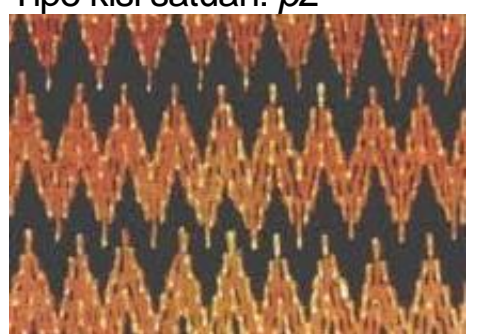

Motif: Tirta Teja

Tipe kisi satuan: $p m g$

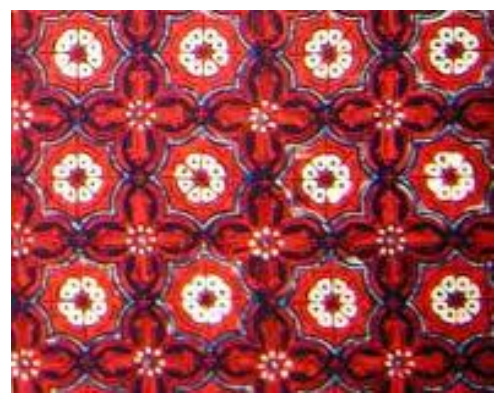

Motif: Ceplok Ganggong

Tipe kisi satuan: $p 4 m$

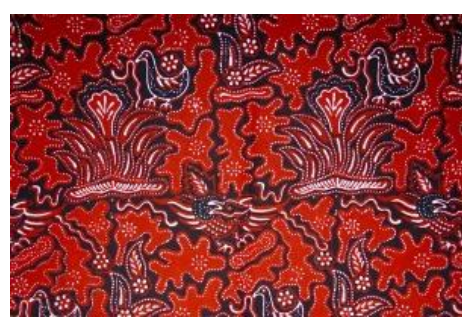

Motif: Jahe Serimpang

Tipe kisi satuan: $p m$

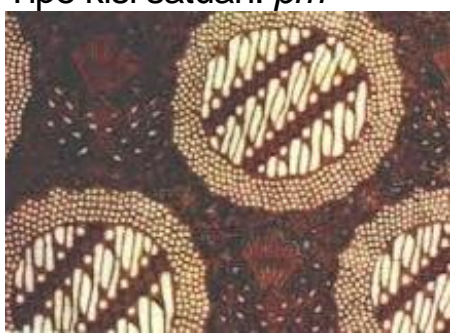

Motif: Parang Kurung

Tipe kisi satuan: $\mathrm{cmm}$

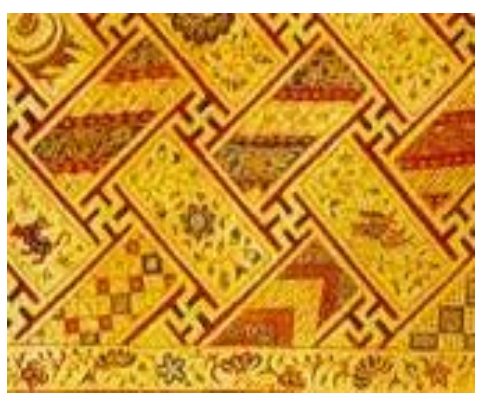

Motif: Banji

Tipe kisi satuan: $p 4 g$

Gambar 7. Contoh pola/motif batik Indonesia dan tipe kisi satuannya

\section{SIMPULAN}

Pola/motif batik di Indonesia dapat dipandang sebagai gambar atau himpunan titik-titik pada bidang yang polanya diulang-ulang dengan cara: pergeseran, perputaran, pencerminan, atau pantul geser. Setiap pola ulangan pada pola batik akan terdapat suatu daerah terbatas sebagai pola dasarnya, mempunyai pergeseran garis lurus yang saling bebas dan terdapat pergeseran dengan vektor terpendek yang memetakan pola pada dirinya sendiri.

Setiap pola ulangan pada motif batik akan membentuk sebuah kisi. Dari lima tipe kisi (yaitu: jajaran genjang, persegi panjang, belah ketupat, bujur sangkar, dan heksagonal) bila dilihat berdasarkan grup simetri bidang yang dimilikinya, maka akan diperoleh 17 tipe grup kristalografi dua dimensi yang masing-masing mempunyai unsur kisi satuan berbeda. Untuk menggambar batik keseluruhan atau secara utuh cukup hanya mengetahui pola dasar beserta kisi satuannya, kemudian dengan cara transformasi isometri akan diperoleh suatu motif batik baru. Ini diperlihatkan pada Lampiran.

Dari penelitian ini, terlihat bahwa batik-batik di Indonesia masing mengumpul pada suatu pola tertentu, untuk itu masih dapat dikembangkan pola batik baru sehingga pola/motif batik Indonesia menjadi lebih kaya dan beragam. 


\section{DAFTAR PUSTAKA}

[1]. N.S. Djumena, Batik dan Mitra. Jakarta, Djambatan, 1990.

[2]. J.R. Durbin, Modern Algebra: An Introduction. 2nd ed. New York, Wiley, 1985.

[3]. Hanzuri, Batik Klasik, Jakarta, Djambatan, 1981.

[4]. D. Schattschneider. "The plane symmetry groups: Their Recognition and Notation", American Mathematical Monthly, vol. 85, no. 6, pp. 430 - 450, 1978.

[5]. A.D.Garnadi, S. Guritman, A. Kusnanto, dan F. Hanum, Survei Pola Grup Krisalografi Bidang Ragam Batik Tradisional, Jurnal Matematika dan Aplikasinya, VOL. 11, NO. 2, Desember, 2012, 1-10 
LAMPIRAN 
SOFTWARE PERANCANG POLA BATIK KONTEMPORER BERBASIS MATEMATIKA

\section{Latar Belakang}

Indonesia merupakan negara yang sangat kaya akan nilai-nilai budaya dan seni yang bercita rasa tinggi. Hal ini disebabkan karena beragamnya suku yang ada di Indonesia sehingga menyebabkan banyaknya nilai-nilai budaya yang ada yang dibawa oleh masing-masing suku tersebut. Salah satu budaya yang merupakan ciri khas Indonesia adalah batik. Batik merupakan salah satu seni budaya khas yang berasal dari Jawa yang sudah ada sejak zaman penjajahan. Pada saat ini, penggunaan batik sudah sangat meluas dan bahkan sekarang sudah banyak produk-produk yang menggunakan batik sebagai komponen utama, antara lain busana, lukisan, perlengkapan rumah tangga (taplak meja, sarung bantal), dan sebagainya. Hasil karya putra-putri Indonesia ini tidak hanya disukai di negeri sendiri bahkan juga dikenal di banyak negara tetangga. Dengan perkataan lain, batik mempunyai nilai ekonomis yang tinggi di samping juga memiliki nilai keindahan sehingga kita harus melestarikan dan mengembangkan seni batik ini.

Saat ini, sudah banyak pola batik yang dihasilkan, terutama yang berasal dari Jawa. Ada lebih dari 100 pola batik tradisional yang sudah diciptakan oleh para perajin batik. Dengan semakin majunya zaman, tuntutan untuk menciptakan suatu pola batik baru atau kontemporer semakin meningkat. Hal ini tentu menuntut kreatifitas dan kerja keras dari para perajin batik.

Apabila kita lihat, ternyata ada suatu kaitan yang kuat antara batik dengan salah satu ilmu Matematika, yaitu Geometri. Geometri merupakan ilmu bangun ruang yang membahas mengenai benda dua dimensi, tiga dimensi, maupun benda $n$ dimensi. Salah satu aplikasi geometri, yaitu mengenai kesimetrisan ternyata dipakai dalam membuat pola batik. Pola-pola batik yang indah itu ternyata merupakan perulangan secara simetri dari suatu pola-pola kecil dan sederhana sehingga pembuatan pola-pola batik baru dapat dilakukan dengan mengaplikasikan ilmu matematika, terutama geometri. 


\section{Perumusan Masalah}

Batik tersusun dari pola-pola yang dilukis di atas bidang datar dan berbentuk dua dimensi. Pola-pola ini jika ditelaah lebih lanjut dapat dilihat menjadi dua bagian :

a. Pola dasar geometris, yaitu pola dasar yang tersusun dari unsur-unsur bentuk geometris.

b. Pola dasar non geometris, yaitu pola dasar yang tersusun atas unsur nongeometris.

Pola dasar geometris biasanya berasal dari dua sumber :

a. Merupakan hasil buatan kreasi sendiri para pembuat batik itu

b. Pola itu timbul karena adanya pengulangan-pengulangan pada suatu pola yang ada.

Penelitian mengenai pola matematika dari batik tradisional Indonesia khususnya Jawa sudah pernah dilakukan oleh Farida Hanum dkk. Berdasarkan penelitian yang sudah dilakukan, didapatkan bahwa pola-pola batik yang sudah ada masih berkumpul dan bentuknya tidak variatif. Hal ini disebabkan karena kemudahan dari beberapa pola batik itu sendiri dan juga penglihatan kita yang terbiasa dengan pola batik tersebut (Farida Hanum dkk,1993). Tetapi, penelitian yang sudah dilakukan mengenai pola batik tersebut tidak membahas mengenai bagaimana membentuk pola batik yang baru.

Oleh karena itu, berdasarkan paparan di atas, maka kami berinisiatif untuk membuat suatu software atau perangkat lunak yang diharapkan dapat membantu para desainer batik dalam membuat pola batik kontemporer yang jarang digunakan dan bisa diubah menjadi suatu pola yang mengagumkan. Pola inilah yang nanti diharapkan dapat menjadi pola-pola yang baru dalam dunia batik Indonesia sehingga akan dapat menambah khasanah budaya Indonesia.

\section{Tujuan}

Tujuan dari program ini adalah menciptakan sebuah software mengenai pembuatan pola batik baru yang dapat mempermudah para pembuat batik dalam memperoleh pola batik yang baru dan jarang digunakan. Selain itu, diharapkan program ini dapat diaplikasikan dan dilakukan kerjasama dengan para pembuat batik. 


\section{Luaran}

Hasil yang diharapkan adalah terciptanya suatu software atau perangkat lunak yang bisa mempermudah dalam penciptaan pola-pola batik. Software ini diharapkan dapat digunakan oleh para perajin batik untuk menciptakan pola batik kontemporer yang jarang digunakan.

\section{Kegunaan}

1. Bagi perguruan tinggi

Program kreatifitas mahasiswa sangat berguna bagi perguruan tinggi. Dengan adanya program ini dapat melatih mahasiswa untuk dapat menumbuhkan ideide kreatif yang mereka miliki. Selain itu dengan adanya program ini dapat menumbuhkan jiwa kompetitif yang tinggi untuk tetap berkarya dalam menggapai prestasi. Sehingga dari hal tersebut dapat meningkatkan kualitas mahasiswa bagi perguruan tinggi yang bersangkutan yang akhirnya dapat meningkatkan nama baik bagi perguruan tinggi yang bersangkutan.

2. Bagi mahasiswa

Melalui program kreatifitas ini diharapkan dapat memberikan tambahan ilmu pengetahuan, wawasan dan pengalaman bagi mahasisiwa. Selain itu melaui program ini juga diharapkan dapat terbentuk suatu jiwa team work yang baik yang nantinya akan sangat berguna ketika sudah masuk kedalam dunia kerja.

3. Bagi masyarakat

Hasil dari program kreativitas ini akan sangat berguna bagi masyarakat, terutama para desainer batik. Diharapkan dengan adanya software ini dapat membantu para desainer batik untuk menciptakan pola-pola batik kontemporer yang belum ada dan jarang dipakai. 


\section{METODOLOGI}

Metodologi yang akan digunakan dalam kegiatan ini adalah :

1. Mengumpulkan informasi.mengenai batik

Pengumpulan informasi ini berupa mendatangi sentra-sentra batik untuk mengenal pola batik yang sudah ada. Selain itu, akan dilakukan juga wawancara dan dialog kepada para perajin batik mengenai pola batik yang sudah ada sehingga diharapkan dari hasil wawancara tersebut memiliki bayangan tentang pola batik yang sudah ada di Indonesia dan juga pola batik kontemporer yang akan dibuat.

2. Merancang software

Pembuatan software atau perangkat lunak ini merupakan kegiatan utama yang diharapkan hasilnya akan semakin mempermudah para desainer batik untuk memperoleh pola batik yang jarang digunakan dan dapat dijadikan pola-pola alternatif.

3. Mengujicoba untuk digunakan pada para perajin batik

Software yang telah ada nanti akan diujicobakan dan diperkenalkan kepada para perajin batik yang ada. Dari ujicoba diharapkan software ini dapat digunakan sebagai alat bantu dalam memperoleh pola batik dan dapat diterima serta digunakan oleh para perajin batik di Indonesia. 


\section{HAL YANG SUDAH DILAKUKAN}

Waktu dan Lokasi

Pembuatan software ini dilakukan sejak bulan Februari 2008 sampai dengan Mei 2008 di Laboratorium Komputer Departemen Matematika, Institut Pertanian Bogor.

\section{Materi}

Secara umum dalam matematika, ada 4 dasar operasi simetri yang menyebabkan sebuah bangun tidak akan berubah bentuknya, yaitu :

a. Translasi (perpindahan)

Suatu gerakan yang memetakan sembarang bidang ke bidang bayangannya sedemikian sehingga setiap bayangannya mempunyai jarak dan arah yang sama dengan asalnya.

b. Rotasi (perputaran)

Suatu gerakan yang memetakan sembarang bidang ke bidang bayangannya dengan cara memutar titik tersebut terhadap suatu titik pusat dengan sudut putar tertentu

c. Refleksi (pencerminan)

Suatu gerakan yang memetakan sembarang bidang ke bidang bayangannya dengan melewati sebuah sumbu simetri baik berupa garis vertical, horizontal, ataupun diagonal yang tegak lurus dengan titik tersebut. Hasil dari pencerminan ini biasanya berbentuk terbalik dengan bidang awal

d. Glide reflection (pantul geser)

Suatu gerakan yang memetakan sembarang bidang ke bidang bayangannya dengan melewati sebuah sumbu simetri kemudian bergerak mengikuti suatu arah yang sejajar dengan sumbu simetri.

Pola pada batik merupakan bagian awal dalam proses pembuatan batik. Pola ini dibangun oleh satuan yang berupa unit di dalamnya. Jika kita lihat, maka di dalam suatu pola itu terdapat kumpulan titik dengan sisinya yang tidak saling overlap. Jika kita misalkan suatu pola itu dengan bidang, maka bidang ini akan diisi dengan poligon-poligon terkecil yang disebut dengan kisi satuan. Terdapat beberapa tipe kisi satuan yang berbeda, yaitu : bujur sangkar, segitiga, segi enam, persegi panjang, jajaran genjang, dan belah ketupat. Pada setiap kisi satuan itu nanti akan dilakukan proses transformasi, baik dengan perpindahan, perputaran, pencerminan, dan pantul geser. 
Dalam ilmu matematika, terdapat 17 sistem transformasi klasik yang merupakan perpaduan dari transformasi pada pola tersebut yang akan menjadi sebuah grup simetri. Ke-17 grup ini disebut sebgaai grup kristalografi dua dimensi. Hasil dari transformasi inilah yang diharapkan akan menjadi suatu pola batik yang mengagumkan.

Pola batik yang ada di Indonesia belum dapat menggambarkan penggunaan 17 pola batik tersebut. Dari pola batik tersebut, ada beberapa pola batik yang bisa digambarkan dengan menggunakan software KSEG-0.401. Pada penelitian ini, bentuk pola yang berhasil dibuat sebanyak 14 buah pola dari 17 pola tersebut. Bentuk pola tersebut adalah sebagai berikut :

Gb 1. Bentuk dengan Pola Refleksi 2 kali (pmm)

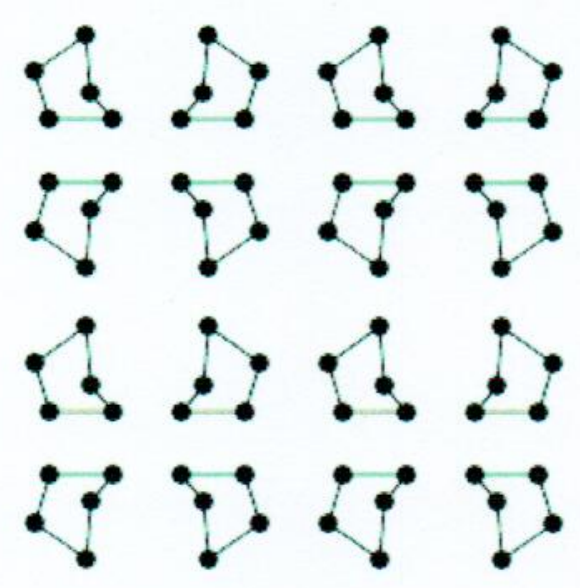

$\mathrm{Gb}$ 2. Bentuk dengan Pola Translasi 1 kali (p1)

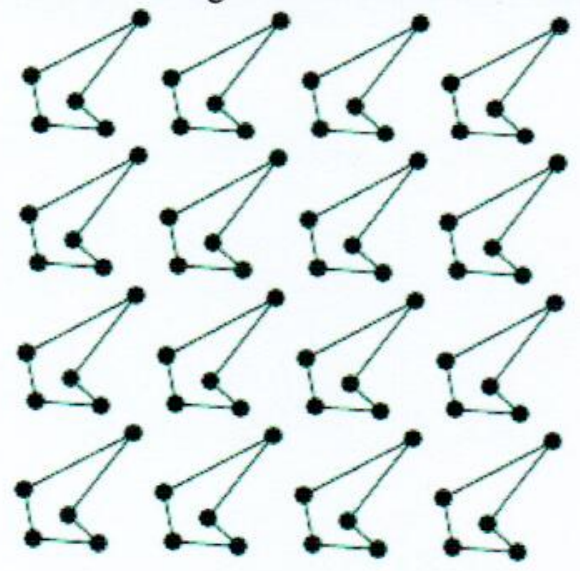


Gb 3. Bentuk dengan Rotasi 2 kali (p2)

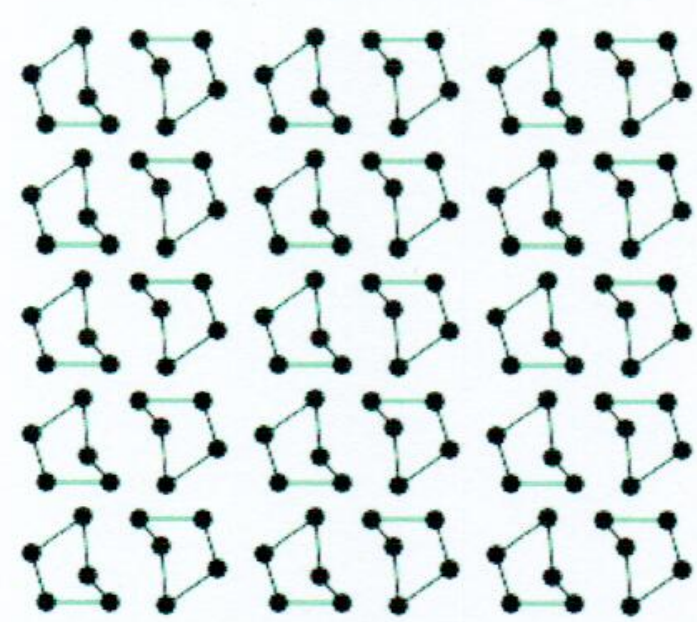

Gb 4. Bentuk dengan Pola Rotasi 3 kali (p3)
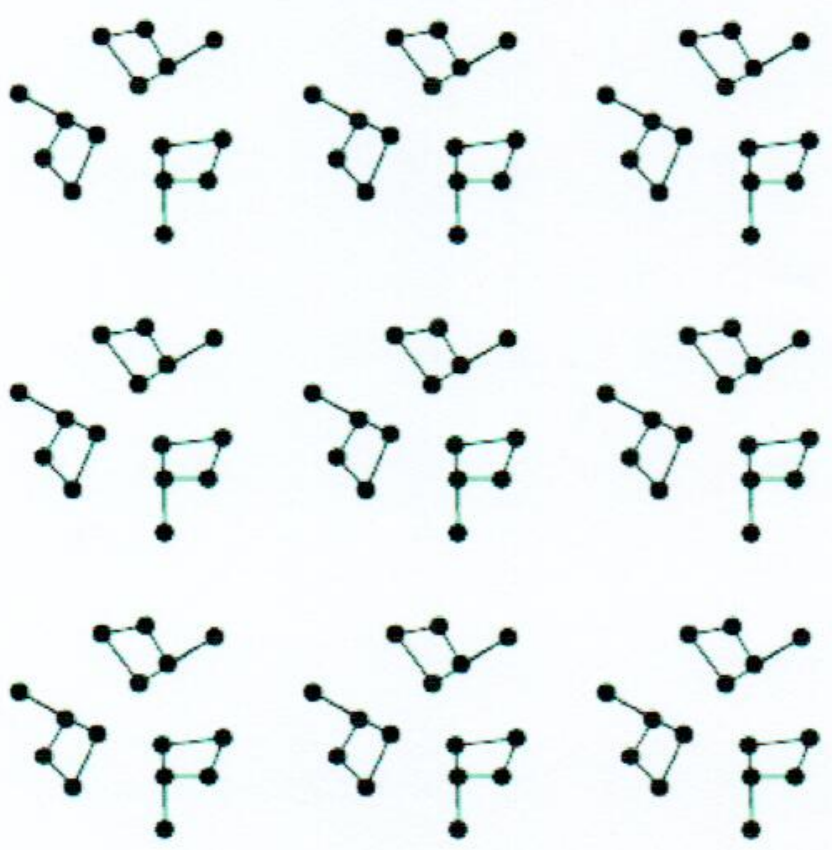
Gb 5. Bentuk dengan Pola Rotasi 4 kali (p4)

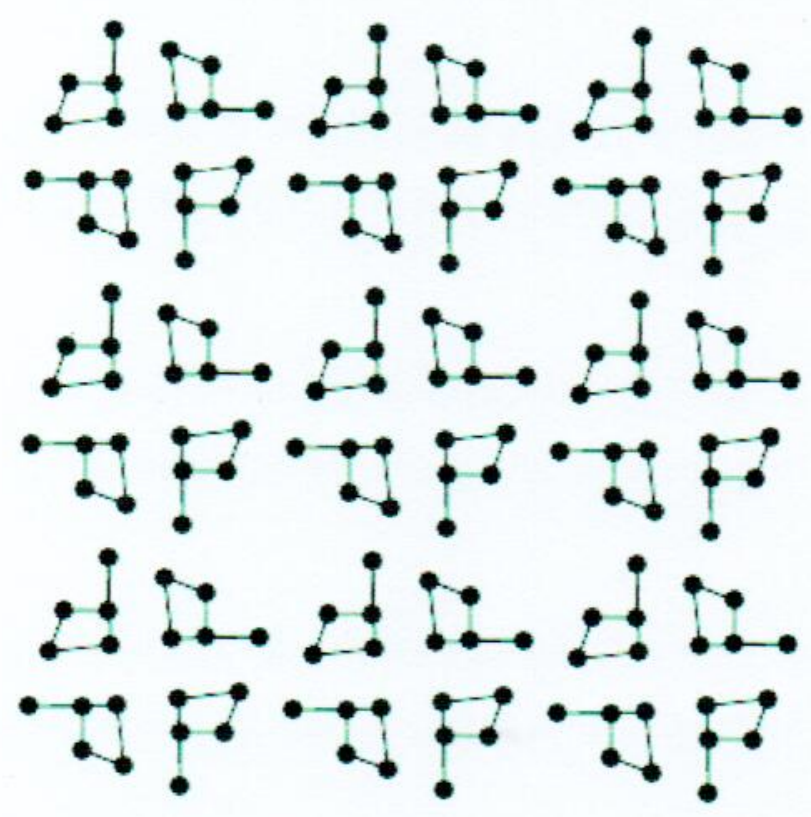

Gb 6. Pola batik "Banji Kasut Latar Ireng" dengan Refleksi + Rotasi 4 kali (p4m)

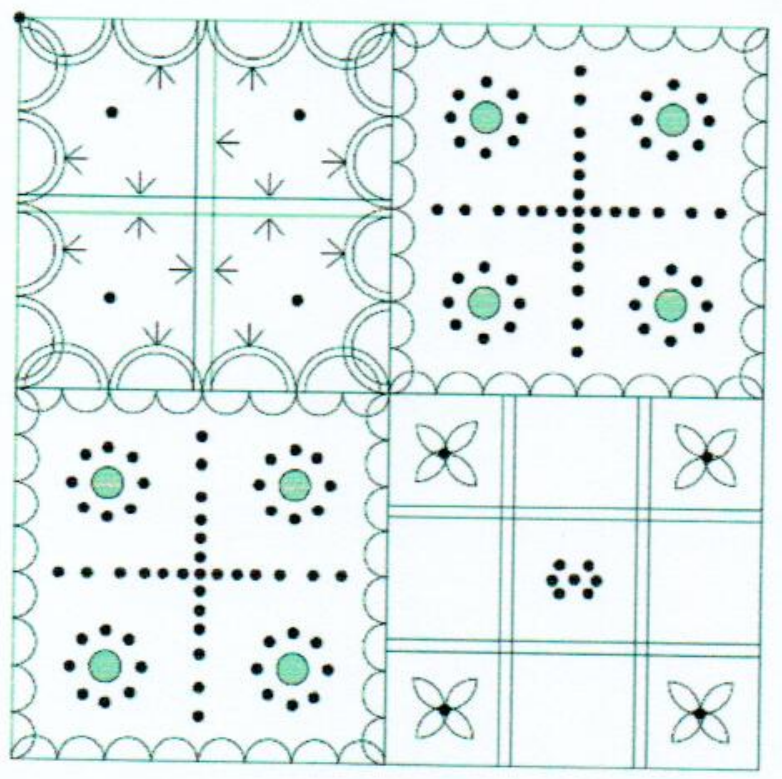


Gb 7. Pola batik "Grompol" dengan Refleksi + Rotasi 4 kali (p4m)

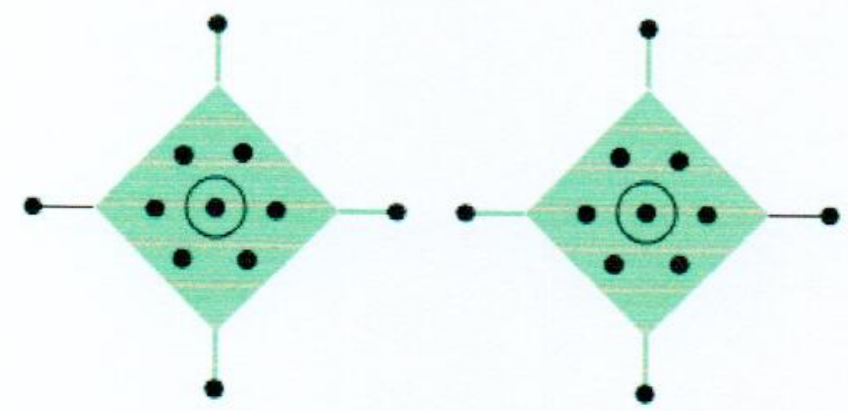

Gb 8. Pola Batik "Kembang Waru" dengan Refleksi + Rotasi 4 kali (p4m)

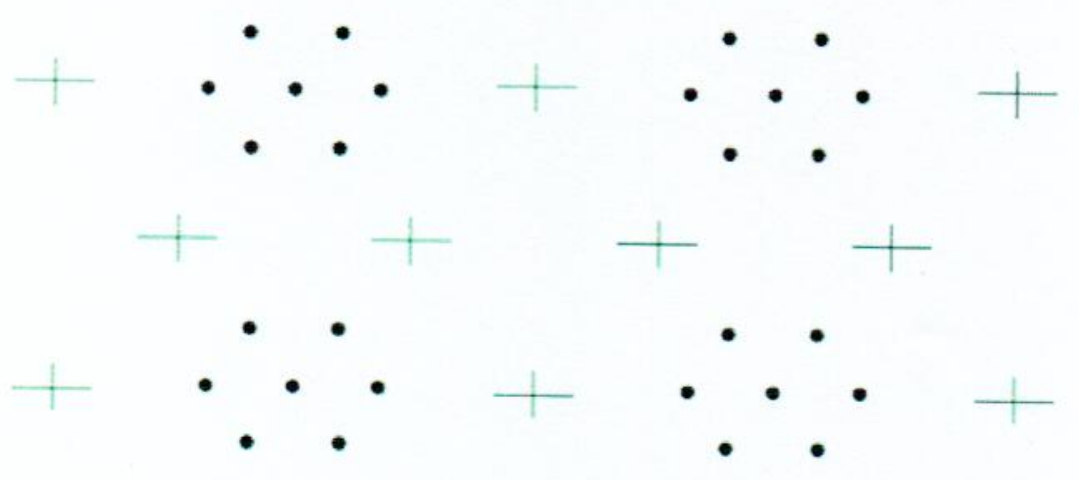


Gb 9. Bentuk dengan Pola Refleksi + Rotasi 4 kali (p4m)

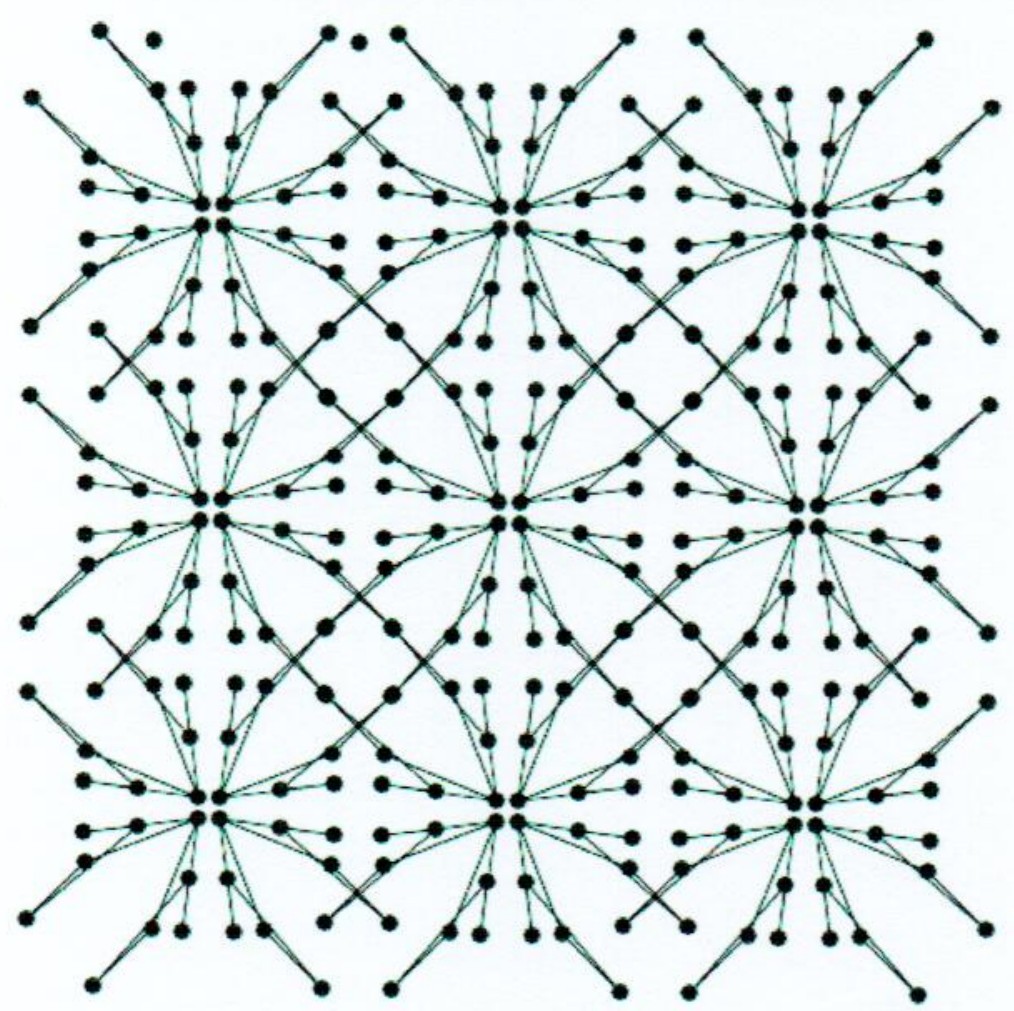

Gb 10. Bentuk dengan Pola Refleksi + Rotasi 4 kali (p4m)

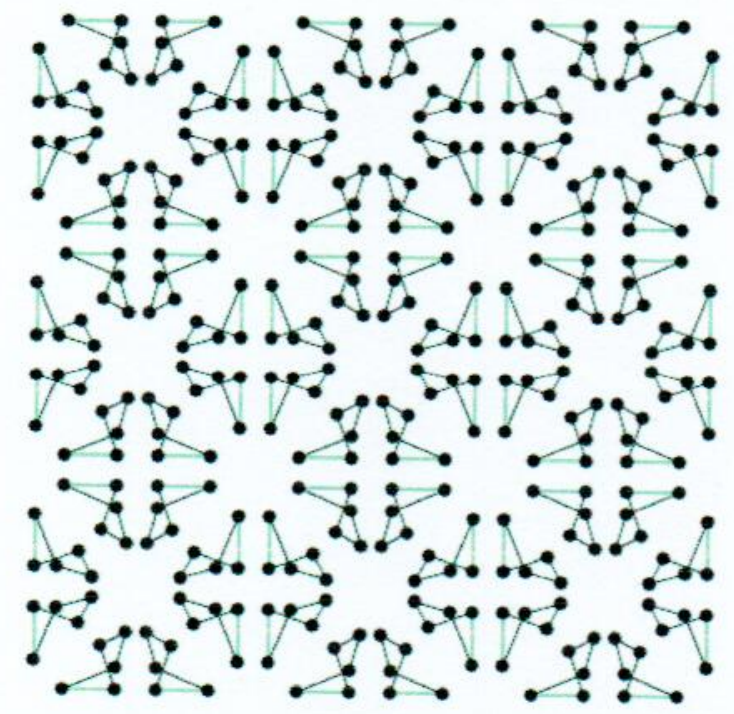


Gb 11. Bentuk dengan Pola Rotasi 6 kali (p6)

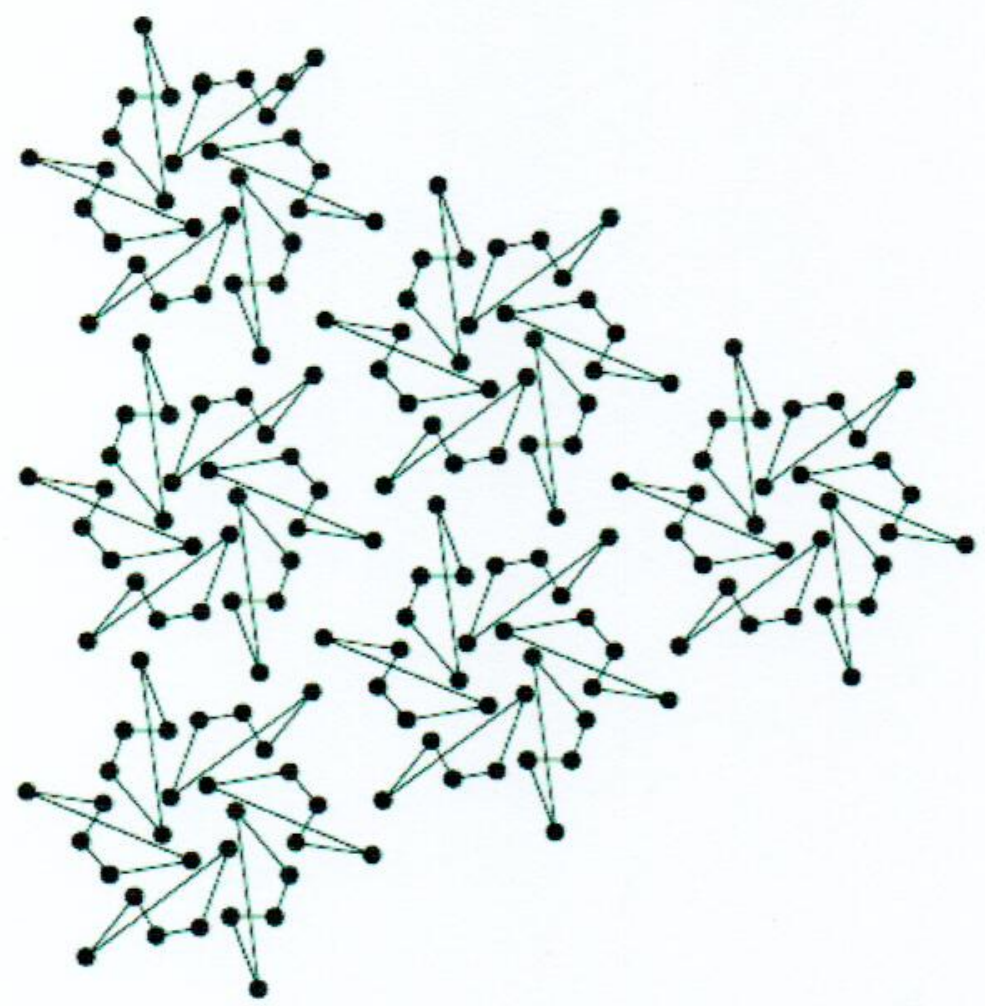

Gb 12. Bentuk dengan Pola Pantul Geser (pg)

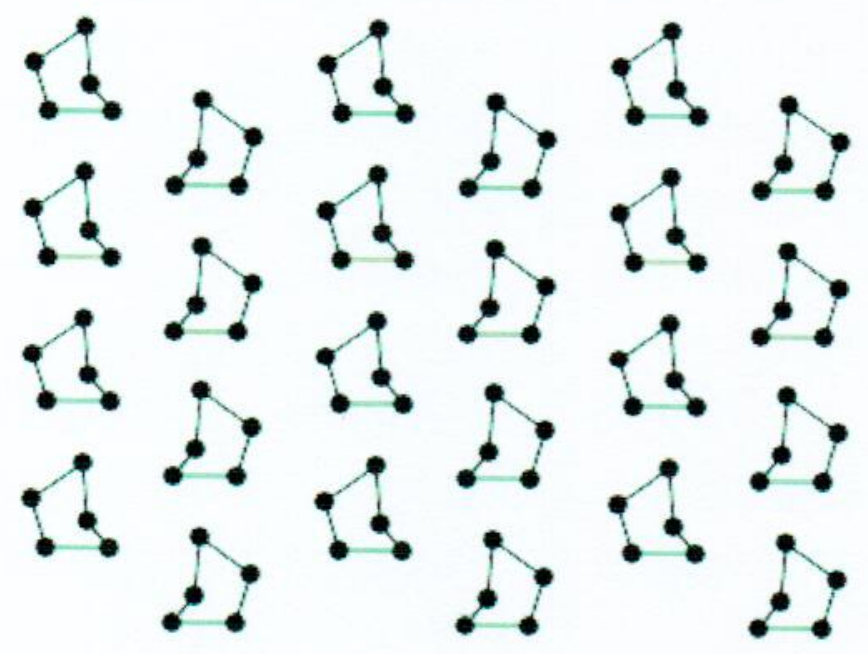


Gb 13. Bentuk dengan Pola Refleksi 1 kali (pm)
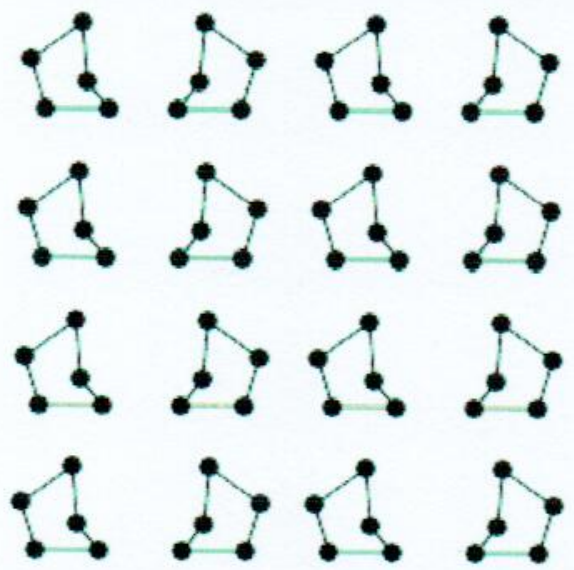

Gb 14. Bentuk dengan Rotasi 4 kali + Pantul Geser (p4g)

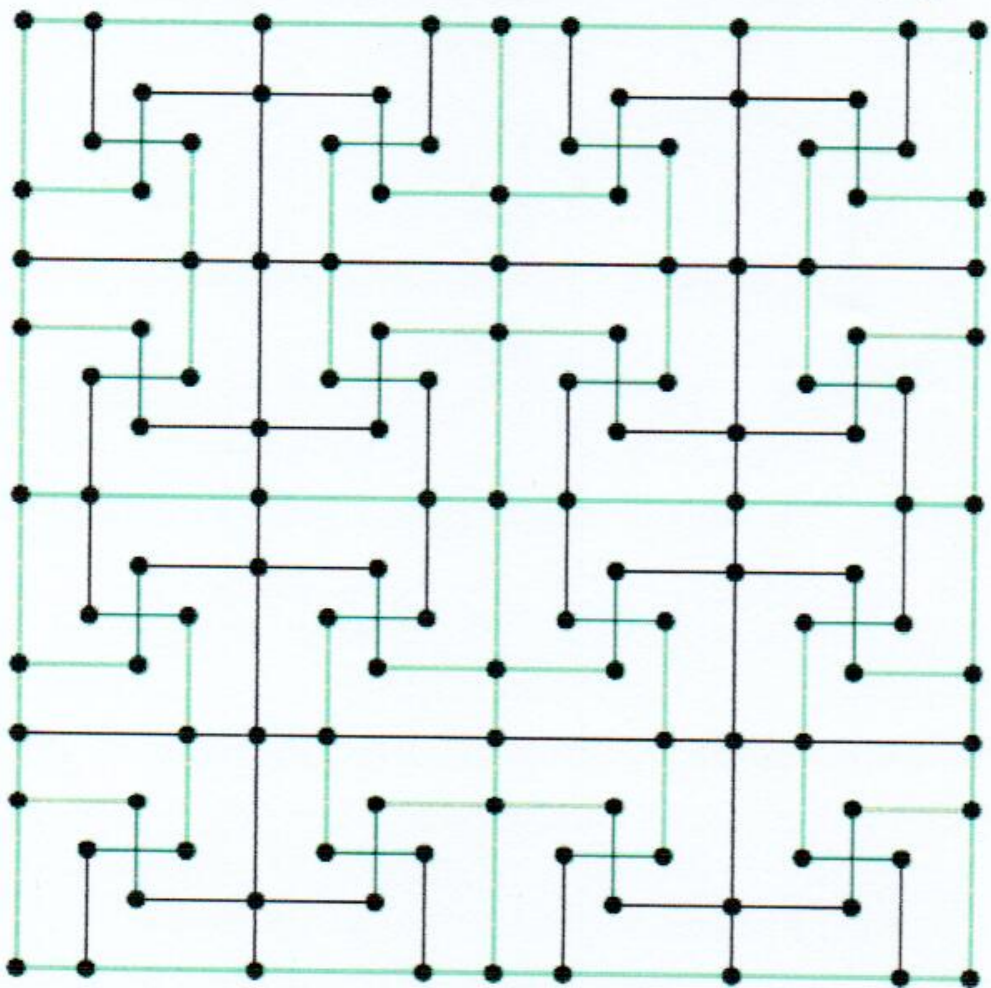


Gb 15. Bentuk dengan Refleksi + Pantul Geser (pgg)

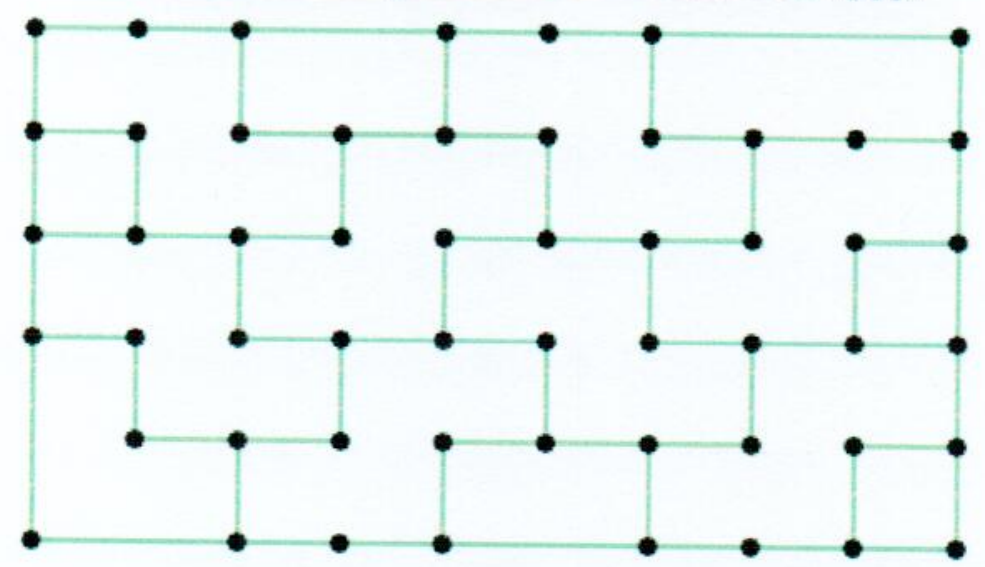

Gb 16. Bentuk dengan Rotasi 2 kali + Refleksi 2 kali (cmm)

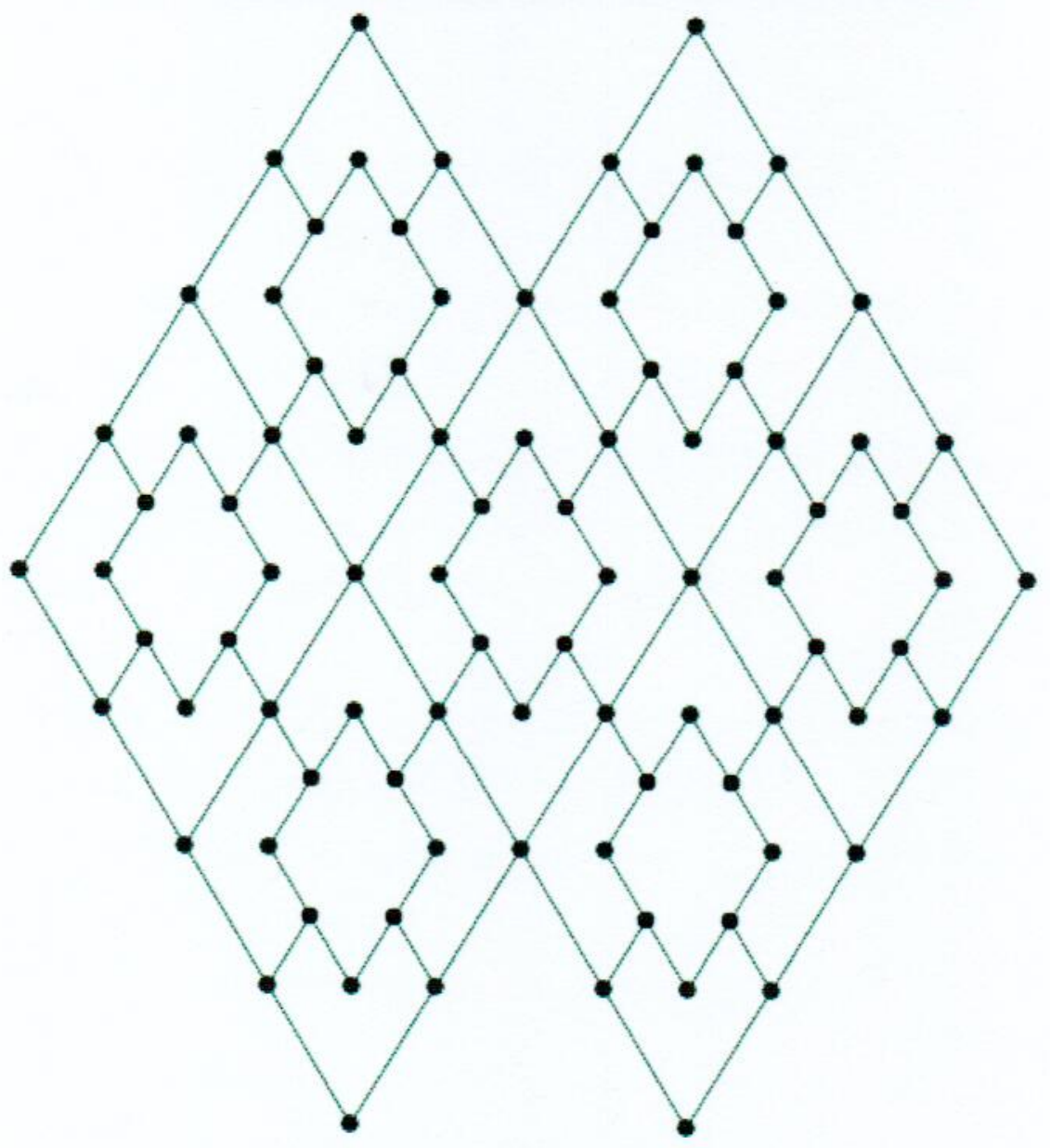


Gb 17. Bentuk dengan Pola Rotasi 3 kali + Refleksi 1 kali (p3m1)

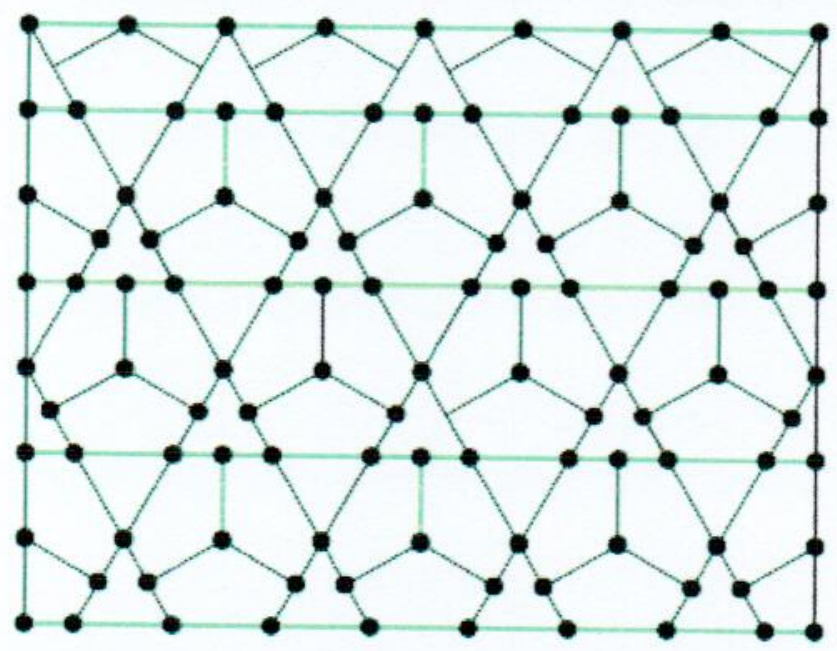

Gb 18. Bentuk dengan Pola Rotasi 6 kali + Refleksi (p6m)

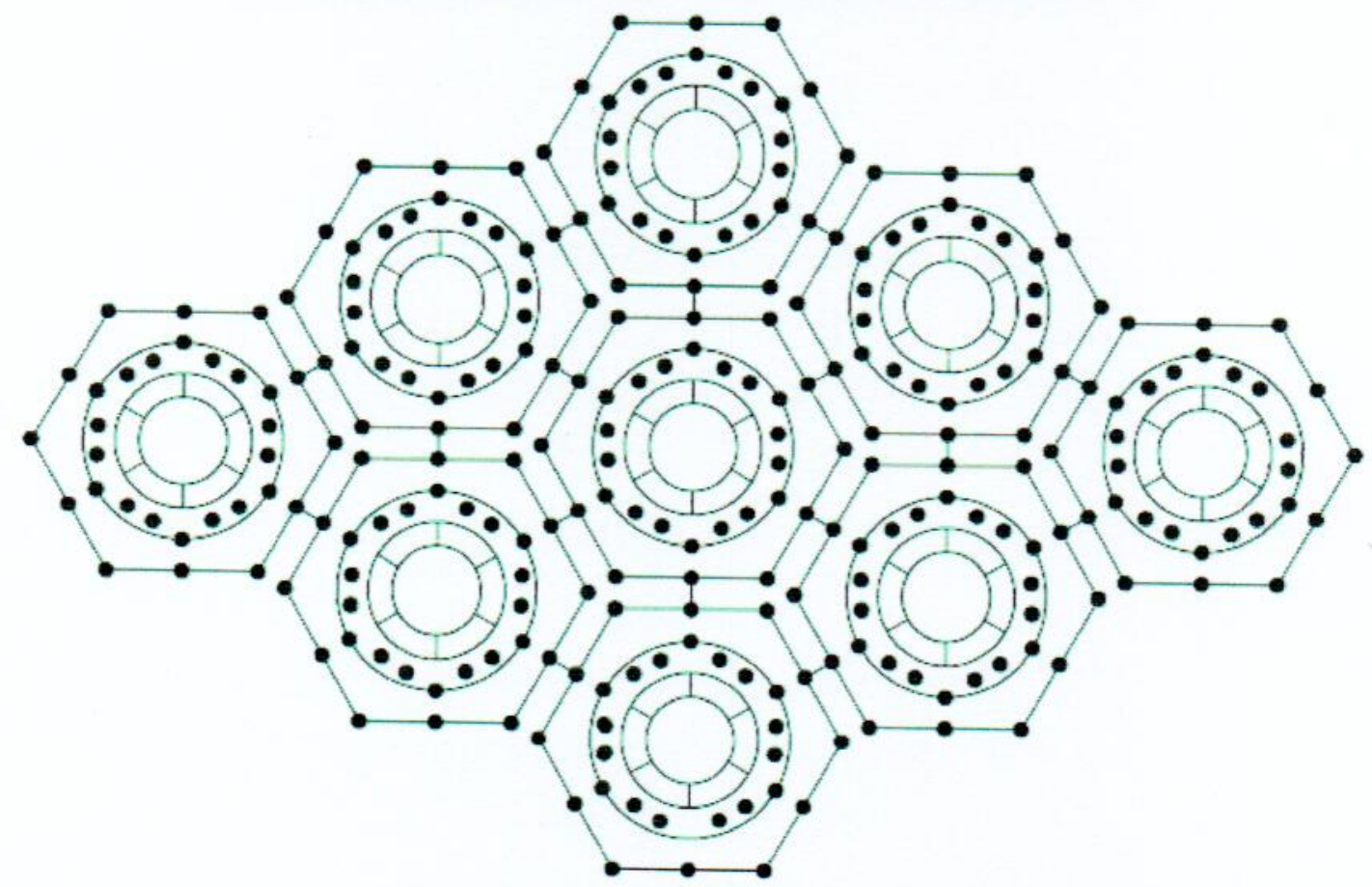

Bentuk-bentuk dan pola-pola batik yang digambarkan di atas hanya merupakan hasil yang dibuat dengan menggunakan software KSEG-0.401 dan belum semua pola dapat digambarkan dengan baik, terutama untuk pola-pola yang bentuk dasarnya merupakan bentuk yang tidak simetris seperti garis melengkung. Gambar di atas merupakan beberapa bentuk rancangan sendiri dan beberapa pola merupakan pola batik tradisional yang memiliki hubungan dengan bentuk geometri matematika. 


\section{LAMPIRAN}

Dalam matematika, terdapat 17 buah variasi perpindahan yang dapat digabungkan dan dikelompokkan menjadi sebuah grup simetri. Ke-17 perpindahan ini merupakan pola dasar perpindahan yang dapat digunakan dalam membuat suatu pola batik. Ke-17 pola ini dapat disebut sebagai grup kristalografi dua dimensi. Kita misalkan, kita ambil huruf $\mathrm{F}$ sebagai bidang dasar. Maka bidang tersebut akan menghasilkan gambar seperti di bawah ini dan akan menghasilkan suatu gambar yang indah :

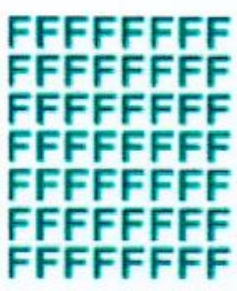

Translasi

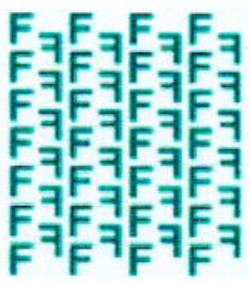

Pantul geser

\section{F가들 \\ F 가갈 \\ F가글 \\ F카가커 \\ F가다커 \\ F카가컥

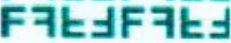

Refleksi+rotasi(2)

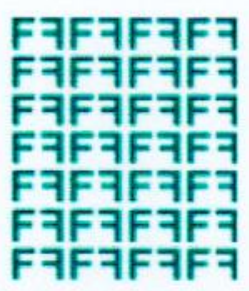

refleksi

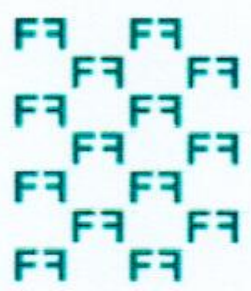

refleksi +

pantul geser

$F \exists F \exists F \exists \exists$

크그큰

$F \exists F \exists F A F A$

크그크

$\mathrm{F} J \mathrm{~F} J \mathrm{~F} J \mathrm{~F} \exists$

그그큰

$F \exists F \exists F \exists F \exists$

Rotasi(2) +

pantul geser

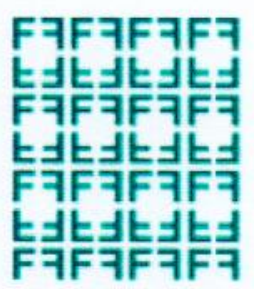

Refleksi 2 kali

\section{$F \exists F \exists F \exists F \exists$ \\ $F \exists F \exists F \exists$ \\ $F \exists F \exists F \exists F \exists$ \\ $F \exists F \exists F \exists F \exists$ \\ $F \exists F \exists F \exists F \exists$ \\ $F \exists F \exists F \exists F \exists$ \\ $F \exists F \exists F \exists F \exists$}

rotasi (2)

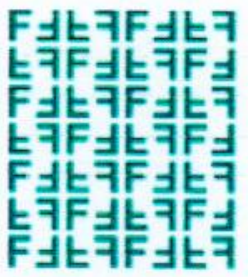

$\operatorname{rotasi}(2)+$

refleksi + refleksi 


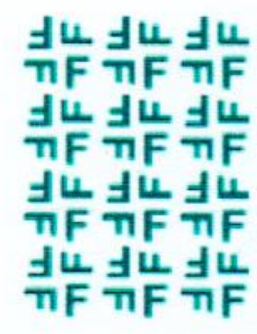

rotasi (4)

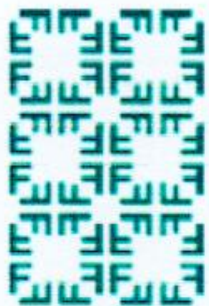

refleksi +

rotasi (4)
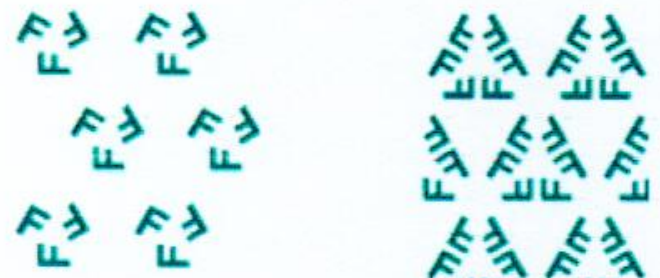

rotasi (3)

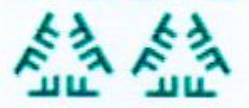

refleksi + rotasi (3)

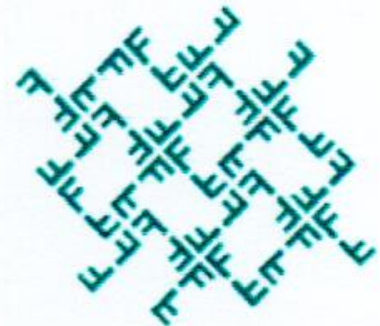

rotasi $(4)+$

refleksi

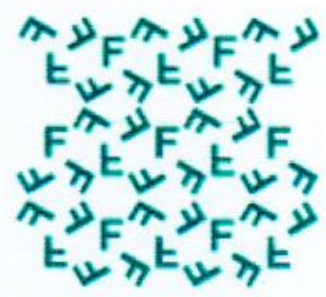

rotasi (3) +

refleksi

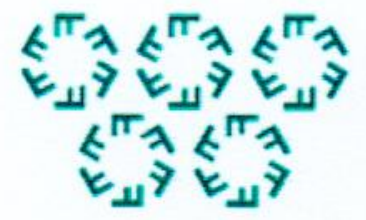

rotasi (6)

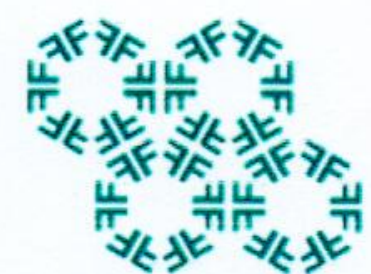

refleksi +

rotasi (6)

Untuk rotasi, perputaran dapat dilakukan dengan beberapa macam sudut istimewa, antara lain :
a. Sudut $30^{\circ}$ jika ia diputar sebanyak 6 kali.
b. Sudut $60^{\circ}$ jika ia diputar sebanyak 3 kali.
c. Sudut $90^{\circ}$ jika ia diputar sebanyak 4 kali.
d. Sudut $180^{\circ}$ jika ia diputar sebanyak 2 kali. 